\title{
ANALISIS PENGARUH PENGELOLAAN LAHAN PERTANIAN BERBASIS ADAT-ISTIADAT TERHADAP KESEJAHTERAAN MASYARAKAT
}

\author{
Liza Yani ${ }^{\mathrm{a}^{*}}$ Mukhlis M.Nur,LC,MA ${ }^{\mathrm{a}^{*}}$ \\ ${ }^{a}$ Faculty of Economics and Business, Malikussaleh University \\ *Corresponding author : lizayani@gmail.com \\ *mukhlish.mnur@unimal.ac.id
}

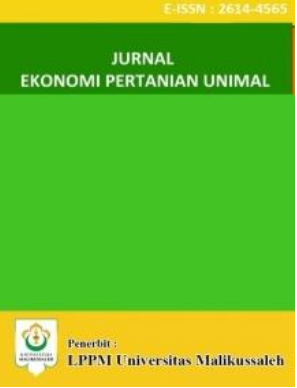

A R T I C L E I N F O R M A T I O N
Keywords: Custumary-based
agricultural land
manajement, welfare of society.

A B S T R A C T

Thish study aims to determine and analyze the influence of custumarybased agricultural land management on the welfare of the community in gampong cemeucet, kuta makmur subdistrict,norsh aceh regency, this study uses primary data obtained from the distribusion of questionnairies to all reserch respondents.The sampling method used is the total sampling method and the number of samples used is 30 respondent who have customary-based agricultural land.The data analysis menthod used is simple linear regression.The results partially show that custumary-based agricultural land management had an effect on on the welfare of the people of gampong cemeucet,kuta makmur subdistrict,north aceh regency, this is evidenced by the value of t-count of 3,971 with a significant value of 0,000 which is higher than t-table with avalue of 1,701 .

\section{PENDAHULUAN}

Indonesia merupakan salah satu negara di dunia yang dapat disebut sebagai negara agraria/agraris, dimana memiliki potensi pertanian yang besar dan dapat berkontribusi terhadap perekonomian nasional. Penduduk Indonesia sebagian besar juga menggantungkan hidupnya dari sektor pertanian. Dimana sector ini terdiri dari peternakan, perikanan dan kehutanan, memiliki potensi yang besar dalam menyerap tenaga kerja di Indonesia, serta prtanian merupakan sektor yang memiliki peranan yang signifikan bagi perekonomian negara. Pertanian di Indonesia mencakup kakao, karet, kelapa sawit dan kopi. Dilihat dari fakta tersebut, para ahli di bidang pertanian di Indonesia mendesak pemerintah agar meningkatkan fokusnya terhadap sektor pertanian, sehingga sektor ini dapat berperan sebagai salah satu faktor penting untuk pembangunan dan perkembangan negara.
Dalam hal ini pembangunan lebih diarahkan pada pembangunan sikap manusia yang mengarah pada peningkatan kualitas hidup agar dapat berpartisipasi aktif dalam pembangunan, karena masyarakat dapat bertindak sebagai para pihak yang memiliki hak dan kewajiban.

Kekayaan hayati dan Sumber Daya Manusia di Indonesia membuat Negara Indonesia cocok dalam bidang pembangunan pertanian yang tidak banyak dimiliki oleh Negara lain (Sukino, 2013). Jumlah petani di Indonesia menurut (BPS, 2016) pada tahun 2017 sebesar 31.705.337 jiwa. Tetapi kemiskinan masyarakat desa yang memilih dan melakukan mata pencahariannya sebagai petani masih sangat tinggi. Terdapat beberapa faktor yang menyebabkan masyarakat petani tersebut masih terus terbelenggu dengan kemiskinan. Faktor alam yang tidak menentu seperti keadaan musim panceklik yang menyebabkan proses tanam menjadi terganggu. Tentunya semua itu sebab akibat oleh tangantangan manusia sendiri yang membuat keseimbangan alam menjadi terganggu. Industri yang berlebihan tanpa menghiraukan dampak lingkungan mengakibatkan global warming. Sikap 
tidak puas oleh masyarakat dengan hasil panen yang kurang memuaskan menyebabkan pemakaian pupuk kimia yang berlebihan justru menyebabkan kesuburan tanah terganggu dan menyebabkan hasil panen menjadi menurun. 
Selain itu dukungan dan perhatian pemerintah yang kurang masih membuat masyarakat mengolah lahan pertanian dengan cara tradisional dan penggunaan teknologi masih rendah sehingga juga menyebabkan tingkat kemiskinan masyarakat petani masih relatif tinggi. Hal ini juga diperparah dengan semakin bertambahnya penduduk Indonesia yang menyebabkan lahan pertanian menjadi berkurang karena lahan pertanian berubah menjadi tempat pemukiman. Lahan pertanian yang telah terwariskan kepada generasi selanjutnya menjadi lebih sempit/kecil, sehingga lahan yang di garap oleh para petani-pun menjadi lebih sempit pula, dan hasilnya tidak dapat mencukupi kebutuhan keluarganya. Hal ini terlihat bahwa petani gurem atau petani dengan jumlah yang luas lahannya kurang dari 0,5 hektar memiliki prosentase 54\% dan petani yang tidak memiliki lahan atau hanya sebagai buruh tani memiliki prosentase $27 \%$ (data BPS, 2016).

Belum lagi dengan kurangnya proteksi dari pemerintah terhadap petani sehingga para tengkulak dengan mudah dapat mempermainkan harga yang menyebabkan para petani kembali menjadi korban. Di sisi lain sistem kapitalis sejak Belanda mulai menjajah Indonesia hingga sekarang memberikan pengaruh besar terhadap sistem perekonomian dan pertanian di Indonesia yang telah menggusur nilai-nilai budaya, sosial dan keagamaan dalam kehidupan. Sikap jujur dan tolong menolong yang terkandung dalam nilainilai budaya, sosial dan keagamaan telah terkikis oleh alasan ekonomi. Sifat individualis saat ini mulai tertanam kuat di dalam pola pikir masyarakat Indonesia.

Berdasarkan sensus pemerintah pada tahun 2017, mengenai pertanian, sebagian besar petani memiliki penghasilan yang kurang dari 900.000 rupiah per bulannya untuk menghidupi empat orang anggota keluarga (rata-rata). Jika lahan/tanah yang dimiliki hanya berupa lahan tadah hujan yang biasanya hanya dapat ditanami sekali per tahunnya, petani hanya mendapatkan keuntungan sebesar 300.000 rupiah per bulannya dari padi di lahannya. Padahal, jika dilihat dari hasil sensus pemerintah dalam bidang pertanian pada tahun 2013, memperlihatkan bahwa usaha tanaman berupa padi mendominasi sumber penghasilan utama bagi mereka yang bertani (dan dalam keluarga petani).
Menurut sensus pemerintah pada tahun 2013 dalam bidang pertanian, sektor tanaman pangan merupakan salah satu sektor terbanyak yang memiliki rumah tangga usaha pertanian, terutama tanaman padi sebanyak 17,73 juta rumah tangga. Hal ini menggambarkan bahwa sektor ini (tanaman pangan padi) merupakan faktor yang penting dalam ketahanan pangan Indonesia. Dari dalam sudut pandang ekonomi tingkat pendapatan dan tingkat kesejahteraan berbanding lurus, di mana semakin tinggi pendapatan maka akan semakin tinggi tingkat kesejahteraan masyarakat, begitupun sebaliknya. Maka dalam upaya peningkatan pendapatan diperlukan informasi tentang faktor-faktor yang dapat mempengaruhi pendapatan, yang diterima seseorang guna meningkatkan kesejahteraan petani.

Sebagian besar masyarakat yang ada di Provinsi Aceh hidup dengan bercocok tanam. Namun sistem irigasi di provinsi ini belum cukup teratur, dimana masih banyak yang bergantung pada air hujan dan padi hanya dapat ditanam sekali tiap tahunnya dengan pemrosesan yang sederhana. Selain bertani, masyarakat Aceh cukup gemar berdagang, seperti berdagang hasil bumi, perkebunan serta laut. Perekonomian provinsi Aceh yang bergantung pada sektor pertanian dan pertambangan ini, yang tanpa diimbangi dengan pertumbuhan di sektor lainnya seperti jasa dan industri pengolahan mengakibatkan nilai pengeksporan Aceh dari sektor pertanian cukup rendah karena yang diekspor bukan merupakan barang/bahan yang telah jadi, melainkan bahan yang masih mentah (bahan baku). Perihal ini tidak memberikan dampak yang signifikan pada pertumbuhan perekonomian Aceh. Jadi Aceh harus bisa mengekspor bahan jadi atau minimal bahan setengah jadi, agar nantinya dapat membantu pertumbuhan perekonomian (Gunawan, 2017).

Sektor pertanian adalah salah satu sektor yang cukup penting di Aceh, karena Aceh merupakan daerah agraris dimana sebagian pendapatannya di dapatkan dari pertanian. Dinas Pertanian dalam Tanaman Pangan dan Hortikultura merupakan instansi milik negara yang membantu mengembangkan sektor pertanian di Indonesia. Masyarakat di provinsi Aceh cukup banyak yang tinggal di daerah pedesaan (gampong), dan sebagian besarnya bertani. Hal tersebut, menyebabkan pembangunan 
dalam sektor pertanian menjadi salah satu program prioritas oleh Pemerintah Aceh, sebagaimana yang telah tercantum dalam Rencana Pembangunan Jangka Menengah Provinsi Aceh. Terdapat 3 komoditas pangan yang mendapat perhatian Pemerintah Aceh, yaitu kedelai, jagung dan padi, sesuai dengan target pembangunan nasional (Gunawan, 2017).

Penelitian ini mengambil objek di Gampong Cemeucet Kecamatan Kuta Makmur, Kabupaten Aceh Utara. Masyarakat disini masih memegang teguh nilai-nilai adat istiadat padahal secara umum mayoritas masyarakat di Gampong ini beragama Islam. Baik itu dalam kehidupan sehari-hari sampai sistem bercocok tanam masih menggunakan cara-cara tradisional. Dan secara garis umum masyarakatnya banyak yang berada dibawah keadaan kekurangan atau kemiskinan.

Berdasarkan obervasi menunjukkan bahwa ada beberapa petani dengan jumlah petak alami, luas lahan (Ha) yang berbeda. Petani tersebut mengelola lahan pertanian secara berkelompok dan secara individual, kebanyakan dari mereka berasal dari keluarga yang kurang sejahtera dari segi pendapatannya. Penghasilan utamanya hanya diperoleh melalui pengelolaan lahan pertanian dengan menanam berbagai macam tumbuh-tumbuhan yang bernilai jual seperti karet, pinang, coklat, padi dan tanaman muda lainnya. (Wawancara dengan Abdurrahman, Geuchik Gampong Cemeucet Kuta Makmur Kab. Aceh Utara).

Tingkat kesejahteraan petani di Gampong ini masih rendah, hal ini terlihat kehidupan sehari-hari dari petani tersebut. Hal ini disebabkan karena sistem pengelolaan tanah pertanian yang tradisional, atau masyarakat belum melakukan inovasi yang membuat lahan dikelola dengan sistem teknologi agar lahan tergarap dengan maksimal sehingga hasilnya juga akan lebih banyak dan bahkan bisa beberapa kali panen dalam setahun. Sistem pengelolaan lahan saat ini masih dipertahankan karena terbatasnya modal dan pengetahuan petani. (Wawancara dengan Mahmudin, Sekretaris Gampong Cemeucet, Kecamatan Kuta Makmur, Kabupaten Aceh Utara).

\section{Rumusan Masalah}

Rumusan dari latar belakang yang tertulis diatas dan agar dalam penelitian ini tidak terjadi kerancuan, maka peneliti akan menentukan batasan dan merumuskan permasalahan yang akan di bahas dalam adalah seberapa besar pengaruh pengelolaan lahan pertanian berbasis adat-istiadat terhadap kesejahteraan masyarakat di Gampong Cemeucet Kecamatan Kuta Makmur, Kabupaten Aceh Utara?

\section{KAJIAN TEORITIS}

\section{Lahan pertanian Berbasis Adat-Istiadat}

Para Ulama menyimpulkan bahwa adat istiadat yang baik secara sah dapat dijadikan landasan hukum, bilamana memenuhi beberapa persyaratan (Beny Primada, 2015).

Secara spesifik, pengertian pengelolaan lahan pertanian adalah setiap tindakan yang diberikan pada lahan untuk menjaga dan meningkatkan produktivitas lahan dengan mempertimbangkan kelestariaannya kedepan (Djaenuddin, dkk., 2006).

Dalam sistem pertanian berkelanjutan, pengelolaan lahan merupakan suatu komponen dari pengelolaan teknologi pertanian.

\section{Lahan}

Menurut (Purwowidodo, 1983) lahan mempunyai pengertian: "Suatu lingkungan fisik yang mencakup relief tanah, tumbuhan, hidrologi, dan iklim sampai suatu batas tertentu yang akan mempengaruhi kemampuan penggunaan suatu lahan".

Lahan juga diartikan sebagai "Permukaan daratan dengan benda-benda padat, cair bahkan gas" (Rafiee I, 1985).

\section{Pertanian}

Pertanian merupakan suatu proses produksi khas yang didasarkan atas proses pertumbuhan tanaman serta hewan petani pengatur dan menggiatkan pertumbuhan tanaman dan hewan tersebut.

Menurut (Mubyarto, 1989), adalah Ilmu ekonomi pertanian adalah termasuk dalam kelompok ilmu - ilmu kemasyarakatan yaitu ilmu yang mempelajari perilaku dan upaya serta hubungannya antarmanusia.

\section{Kesejahteraan}

Setiap manusia mempunyai keinginan untuk dapat sejahtera, dimana kesejahteraan tersebut menunjuk kepada suatu keadaan yang 
serba baik atau suatu kondisi dimana manusia dalam keadaan sehat, makmur serta damai. Menurut kamus Bahasa Indonesia, sejahtera berarti makmur, aman sentosa serta terlepas dari segala hal gangguan.

\section{Konsep Kesejahteraan Masyarakat Dalam Islam}

Pertumbuhan ekonomi merupakan sarana untuk mencapai keadilan distributif, karena mampu menciptakan lapangan pekerjaan yang baru, dengan terciptanya lapangan kerja baru maka pendapatan riil masyarakat akan meningkat, dan ini merupakan salah satu indicator kesejahteraan dalam ekonomi Islam, tingkat pengangguran yang tinggi merupakan masalah yang memerlukan perhatian serius seperti halnya dalam ekonomi kapitalis, hanya saja dalam pemikiran liberal, tingkat pengangguran yang tinggi bukan merupakan indikator kegagalan system ekonomi kapitalis yang didasarkan pada pasar bebas, hal itu dianggap sebagai proses transisional, sehingga problem itu dipandang akan hilang begitu pertumbuhan ekonomi mengalami peningkatan (Naqvi, 2003).

\section{Hipotesis}

Berdasarkan tinjauan teoritis dan kerangka pikir yang telah dijelaskan sebelumnya, dimana hipotesis untuk/dalam penelitian ini adalah sebagai berikut :

$\mathrm{H}_{0}$ : Diduga bahwa pengelolaan lahan pertanian berbasis adat-istiadat tidak berpengaruh terhadap kesejahteraan masyarakat di Gampong Cemeucet Kuta Makmur, Kab. Aceh Utara.

$\mathrm{H}_{\mathrm{a}}$ : Diduga bahwa pengelolaan lahan pertanian berbasis adat-istiadat berpengaruh terhadap kesejahteraan masyarakat di Gampong Cemeucet Kuta Makmur, Kab. Aceh Utara.

\section{METODE PENELITIAN}

\section{Populasi dan Sampel}

Populasi

Menurut Sugiyono (Sugiyono, 2014), populasi merupakan suatu wilayah generalisasi, obyek/subyek yang memiliki suatu karakteristik dan kualitas tertentu yang telah ditetapkan oleh peneliti untuk dipelajari dan kemudian suatu ditarik kesimpulan darinya.
Populasi dalam penelitian ini adalah petani yang mengelola lahan pertanian berbasis adat istiadat untuk kesejahteraan hidup sehari-hari dan masa depan. Berdasarkan hasil data observasi, jumlah petani yang menjadi populasi sebanyak 30 petani.

\section{Sampel}

Sampel merupakan suatu bagian dari karakteristik dan jumlah yang dipunyai oleh populasi (Sugiyono, 2014). Untuk dapat menentukan berapa besarnya suatu sampel, maka perlu mempertimbangkan pendapat ahli mengenai penentuan besarnya sampel.

Dalam penentuan berapa jumlah sampel dalam penelitian ini, sesuai dengan jumlah populasi yaitu berjumlah 30 responden untuk petani yang mengelola lahan pertanian berbasis adat istiadat.

\section{Definisi Operasional Variabel Penelitian}

Definisi ini diberikan agar tidak terjadi kesalahan dalam penafsiran terhadap suatu variabel yang ada. Variabel-variabel tersebut, yaitu :

1. Pengelolaan lahan pertanian yang berdasar adat-istiadat (X) merupakan pengelolaan suatu lahan pertanian adalah setiap tindakan yang diberikan pada suatu lahan untuk menjaga dan meeningkatkan produktivitas lahan tersebut dengan mempertimbangkan kelestariaannya (Djaenuddin, dkk, 2006).

2. Kesejahteraan masyarakat (Y) merupakan kesejahteraan masyarakat merupakan suatu kondisi yang memperlihatkan keadaan kehidupan suatu masyarakat yang dapat dilihat dari standar kehidupannya (Badrudin, 2012).

\section{Metode Analisis Data}

Metode analisis yang digunakan dalam penelitian ini merupakan analisis model regresi sederhana. Persamaan regresi sederhana adalah persamaan regresi yang hanya menggunakan satu variabel dalam suatu analisa. Tujuannya untuk menghitung parameter estimasi dan untuk melihat apakah variabel bebas mampu menjelaskan variabel terikat dan memiliki suatu pengaruh. 
Variabel yang akan diestimasi adalah variabel terikat, sedangkan variable lain yang mempengaruhinya adalah variabel bebas.

Metode analisa yang digunakan untuk menjawab hipotesis adalah regresi linier berganda dengan pengolahan data menggunakan software SPSS (Statistical Package for Social Science). Menurut Nazir (Nazir, 2009), jika parameter dari suatu hubungan fungsional antara satu variabel dependen dengan lebih dari satu variabel independen ingin diestimasikan, maka disebut regresi linear sederhana. Formulasinya adalah sebagai berikut:

Keterangan:

$$
\mathbf{Y}=\boldsymbol{\alpha}+\boldsymbol{\beta} \mathbf{X}+\boldsymbol{\varepsilon}
$$

$\mathrm{Y}=$ Kesejahteraan masyarakat

$\mathrm{X}=$ Pengelolaan lahan pertanian berbasis adat-istiadat

$\alpha \quad=$ Konstanta

$\beta=$ Nilai koefisien regresi dianggap konstan

$\varepsilon=$ error term

\section{Uji Asumsi Klasik}

\section{Uji Normalitas}

Uji normalitas ditujukan untuk mengetahui apakah dalam suatu model regresi, variabel terikat dan variabel bebas memiliki distribusi yang normal atau tidak.

\section{Uji Heterokedastisitas}

Tujuan pengujian ini adalah untuk mengetahui apakah dalam suatu model regresi terjadi ketidaksamaan variance dari residual satu pengamatan ke pengamatan yang lainnya. Jika variance dari residual satu pengamatan ke pengamatan yang lainnya tetap, maka disebut homokedastisitas, namun jika berbeda, disebut sebagai heterokedastisitas. Dimana untuk mendeteksi terdapat atau tidaknya heteroskedastisitas, perlu dilakukan dengan cara melihat grafik. Menurut Ghozali (Ghozali, 2005), jika tidak ada suatu pola yang jelas, serta titiktitiknya menyebar di atas dan di bawah angka 0 pada sumbu Y, maka tidak terjadi suatu heteroskedastisitas.

\section{Hasil Penelitian}

\section{Hasil uji asumsi klasik}

Hasil uji normalitas

Hasil pengujian normalitas bisa dilihat dalam Gambar 4.1 dibawah:

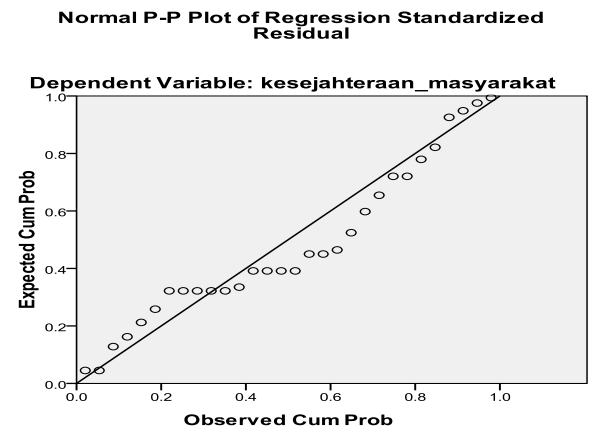

Gambar 4.1. Uji Normalitas P-P Plot

Sumber: Hasil Penelitian, Data diolah (Oktober, 2019).

Gambar 4.1 di atas menunjukkan bahwa titik-titik residual model regresi sudah berdistribusi normal, hal ini dikarenakan titik-titik tersebut menyebar di sekitar garis diagonal. Berarti, syarat kenormalan sebagai pengujian statistik dengan menggunakan regresi dapat terpenuhi.

\section{Uji Heteroskedastisitas}

Pengujian heteroskedastisitas dapat dilihat pada Gambar 4.2 dibawah ini

Tabel 1.1

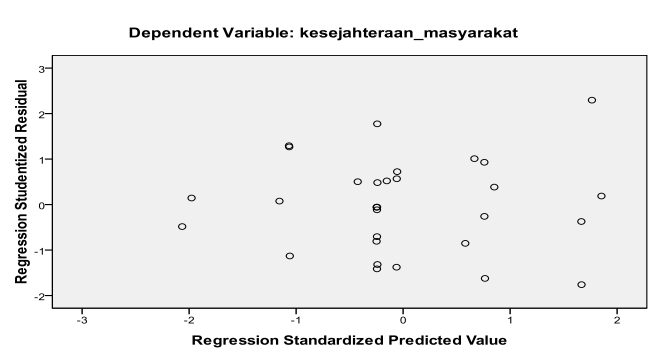

\section{Gambar 4.2 UjiHeteroskedastisitas}

Sumber: Hasil Penelitian, Data diolah (Oktober, 2019).

Gambar 4.2 di atas menunjukkan bahwa titik-titik data menyebar di atas dan dibawah atau sekitar angka 0 pada sumbu Y, maka berdasarkan metode grafik, tidak terjadi suatu heteroskedastisitas pada model regresi.

\section{Uji Statistik}




\section{Uji Hipotesis}

Hasil uji-t dapat dilihat pada Tabel 4.11 dibawah ini:

Tabel 4.11

Hasil Pengujian Secara Parsial (Uji-t)

\begin{tabular}{|c|c|c|}
\hline Model & $\mathrm{t}$ & $\mathrm{Sig}$ \\
\hline 1. (Constan) & 1.930 & .064 \\
$\begin{array}{l}\text { Pengelolaan } \\
\text { Lahan pertanian } \\
\text { Berbasis Adat- } \\
\text { Istiadat }\end{array}$ & 3.971 & .000 \\
\hline
\end{tabular}

Sumber: Hasil Penelitian, Data diolah (Oktober, 2019).

Berdasarkan hasil penelitian diatas dapat dilihat bahwa nilai t-hitung sebesar 3.971 dengan nilai signifikan sebesar 0.000 dan lebih besar dari t-tabel dengan nilai 1.701. Dari hasil penelitian jika dikaitkan dengan kenyataan bahwa pengelolaan lahan pertanian berbasis adat-istiadat sangat berpengaruh terhadap kesejahteraan masyarakat di lokasi penelitian karena dengan demikian pengelolaan lahan pertanian berbasis adat-istiadat selama ini belum dianggap penting.

Penelitian menunjukkan semakin baiknya pengelolaan lahan pertanian berbasis adatistiadat, maka semakin baik pula kesejahteraan masyarakat di Gampong tersebut. Perihal ini menunjukkan bahwa pengelolaan lahan pertanian berbasis adat-istiadat berpengaruh positif/baik serta signifikan bagi kesejahteraan masyarakat. Dengan demikian, hipotesis yang menyatakan bahwa pengelolaan lahan pertanian berbasis adatistiadat berpengaruh positif terhadap kesejahteraan masyarakat Gampong Cemeucet, Kecamatan Kuta Makmur, Kabupaten Aceh Utara diterima.

Hasil penelitian ini sejalan dengan penelitian yang dilakukan oleh Primada (Primada, 2015) yang berjudul "Tinjauan Mekanisme Kontrak Pengelolaan Lahan pertanian Berbasis Adat Istiadat Dalam Kajian Fiqh Muamalah (Desa Temu, Kecamatan Kanor, Kabupaten Bojonegoro), Andrian Wira Syah Putra, Sunarru Samsi Hariadi, (Subejo, 2016), "Peran Kejreun Blang Terhadap Perilaku Petani Dalam Pengelolaan Air Pertanian Di Nanggroe Aceh Darussalam, (Gunawan, 2017), "Peran Dinas Pertanian Tanaman Pangan Dan
Hortikultura Kabupaten Aceh Besar dalam Meningkatkan Ekonomi Masyarakat Kecamatan Indrapuri, dimana ada korelasi yang erat antara pengelolaan lahan pertanian berbasis adat-istiadat dengan kesejahteraan masyarakat Gampong Cemeucet, Kecamatan Kuta Makmur, Kabupaten Aceh Utara.

\section{Uji Korelasi $(\boldsymbol{R})$}

Koefisien determinasi pada regresi linear dapat diartikan sebagai seberapa besar kemampuan semua variabel bebas dalam menjelaskan variance dari variabel terikatnya. Koefisien determinasi dihitung dengan mengkuadratkan Koefisien Korelasi (R). Koefisien ini digunakan untuk mengetahui seberapa besar pengaruh variabel-variabel bebas terhadap variabel terikatnya. Nilai koefisien determinasi ditentukan dengan nilai adjusted $R$ Square. Dalam output SPSS, koefisien determinasi terletak pada tabel Model Summary ${ }^{b}$. Untuk hasil koefisien korelasi dan determinasi dapat dilihat pada table dibawah ini:

Tabel 4.12

Hasil Koefisien Korelasi dan Determinasi

\begin{tabular}{|c|c|c|c|c|}
\hline $\begin{array}{c}\text { Mod } \\
\text { el }\end{array}$ & $\mathrm{R}$ & $\begin{array}{c}\mathrm{R} \\
\text { Squa } \\
\text { re }\end{array}$ & $\begin{array}{c}\text { Adju } \\
\text { sted } \\
\mathrm{R} \\
\text { Squar } \\
\mathrm{e}\end{array}$ & $\begin{array}{c}\text { Std. } \\
\text { Error of } \\
\text { the } \\
\text { Estimate }\end{array}$ \\
\hline 1 & $\begin{array}{c}.600 \\
\text { (a) }\end{array}$ & .360 & .337 & 1.46048 \\
\hline
\end{tabular}

a Predictors: (Constant), Pengelolaan Lahan pertanian Berbasis Adat-Istiadat

b Dependent Variable: Kesejahteraan Masyarakat

Sumber: Hasil Penelitian, Data diolah (Januari, 2018).

Berdasarkan Tabel 4.12 di atas, koefisien korelasi (R) sebesar 0,600 atau $60,0 \%$ yang bermakna eratnya hubungan (korelasi) antara pengelolaan lahan pertanian berbasis adat-istiadat dengan kesejahteraan masyarakat artinya hubungan antara pengelolaan lahan pertanian berbasis adat-istiadat terhadap kesejahteraan masyarakat Gampong Cemeucet, Kecamatan 
Kuta Makmur, Kabupaten Aceh Utara sebesar 0,600 .

\section{Uji Determinasi ( $R$ Square)}

Berdasarkan tabel 4.12 di atas, koefisien determinasi ( $R$ Square) sebesar 0,360 atau 36,0\%, artinya variabel pengelolaan lahan pertanian berbasis adat-istiadat mampu memengaruhi kesejahteraan masyarakat sebesar 36,0\%. Sedangkan selebihnya $74,0 \%$ tingkat kesejahteraan masyarakat Gampong Cemeucet, Kecamatan Kuta Makmur, Kabupaten Aceh Utara dipengaruhi oleh variabel-variabel lainnya.

\section{Pembahasan}

\section{Hasil Regresi Linier Sederhana}

Hasil analisis dengan menggunakan model regresi linier sederhana dapat dilihat pada tabel 4.1 dibawah ini:

\section{Tabel 4.1}

Hasil Regresi Linier Sederhana

\begin{tabular}{|c|c|c|c|}
\hline \multirow{2}{*}{ Model } & \multicolumn{2}{|c|}{$\begin{array}{c}\text { Unstandardized } \\
\text { Coefficients }\end{array}$} & $\begin{array}{c}\text { Standardize } \\
\mathrm{d} \\
\text { Coefficients }\end{array}$ \\
\cline { 2 - 4 } & $\mathrm{B}$ & $\begin{array}{c}\text { Std. } \\
\text { Error }\end{array}$ & Beta \\
\hline 1. & (Contsant) \\
$\begin{array}{l}\text { Pengelola } \\
\text { an Lahan } \\
\text { pertanian } \\
\text { Berbasis } \\
\text { Adat- } \\
\text { Istiadat }\end{array}$ & .851 & .205 & .600 \\
\hline
\end{tabular}

a Predictors: (Constant),

b Dependent Variable: Pengelolaan Lahan pertanian Berbasis Adat-Istiadat

Sumber: Hasil Penelitian, Data diolah (Oktober, 2018).

Berdasarkan hasil pengolahan data seperti terlihat pada Tabel 4.10, Kolom Unstandardized Coefficients bagian B diperoleh persamaan regresi linier sederhana sebagai berikut:

$\mathrm{Y}=4,740+.815 \mathrm{X}$

Berdasarkan persamaan tersebut dapat dianalisiskan sebagai berikut:

a. Konstanta (a) $=\mathbf{4 , 7 4 0 ,}$, ini mempunyai arti bahwa variabel pengelolaan lahan pertanian berbasis adat-istiadat terhadap kesejahteraan masyarakat (Y) memiliki hubungan positif sebesar 4,740. Diinterprestasikan apabila variabel pengelolaan lahan pertanian berbasis adatistiadat $(\mathrm{X})$, sama dengan 0 maka kesejahteraan masyarakat akan tetap sebesar 4,740.

b. Nilai Koefisien $\mathbf{X}(\mathbf{b})=\mathbf{0 , 8 1 5}$ pengaruh variabel pengelolaan lahan pertanian berbasis adat-istiadat terhadap kesejahteraan masyarakat memiliki hubungan positif sebesar 0,815. Di interprestasikan jika nilai pengelolaan lahan pertanian berbasis adat-istiadat meningkat sebesar 1\%, maka kesejahteraan masyarakat akan meningkat sebesar 0,815 .

\section{Penutup}

\section{Kesimpulan}

Berdasarkan analisis yang telah dilakukan diatas, maka penulis dapat menarik beberapa kesimpulan sebagai berikut:

1. Pengelolaan lahan pertanian berbasis adatistiadat berpengaruh terhadap kesejahteraan masyarakat hal ini dibuktikan dengan nilai t-hitung sebesar 3.971 dengan nilai signifikan sebesar 0.000 dan lebih besar dari t-tabel dengan nilai 1.701 .

2. Pengelolaan lahan pertanian berbasis adat-istiadat sangat berpengaruh terhadap kesejahteraan masyarakat karena dengan demikian pengelolaan lahan pertanian berbasis adat-istiadat selama ini belum dianggap penting tidak termasuk dalam aspek yang mempengaruhi kesejahteraan masyarakat. Arah hubungan positif dan signifikan tersebut menunjukkan bahwa semakin rendah pengelolaan lahan pertanian berbasis adat-istiadat, maka semakin tinggi pula kesejahteraan masyarakat.

3. Kemudian Koefisien determinasi $(R$ Square) sebesar 0,360 atau $36,0 \%$, artinya variabel pengelolaan lahan pertanian berbasis adat-istiadat mampu 
memengaruhi kesejahteraan masyarakat sebesar 36,0\%. Sedangkan selebihnya $74,0 \%$ tingkat kesejahteraan masyarakat di lokasi penelitian ini dipengaruhi oleh variabel-variabel lainnya yang tidak dimasukkan dalam penelitian ini.

\section{Saran}

Berdasarkan hasil penelitian dan kesimpulan yang telah di sebutkan, terdapat beberapa saran yang penulis dapat sampaikan sehubungan penelitian ini, yaitu:

1. Diharapkan adanya perhatian lebih termasuk pendampingan dan pengawasan terhadap masyarakat petani di lokasi/daerah penelitian terkait mekanisme serta proses penggarapan lahan pertanian sehingga pelaksanaan mekanisme penggarapan lahan pertanian dapat berjalan lancar, maksimal, dan adil terkait pembagian hak dan kewajiban dalam mekanisme penggarapan lahan. Sehingga tidak ada pihak yang dirugikan.

2. Diharapkan kepada peneliti selanjutnya dapat meneliti topik yang lebih mendalam lagi mengenai ekonomi pertanian di di lokasi penelitian ini, kajian-kajian syariah terhadap pola pertanian dan pola perilaku para petani di pedasaan mulai dari proses bertanam sampai pemasaran, manajemen keuangan keluarga petani dan lain-lain yang secara pendidikan dan ilmu pengetahuan masih memiliki keterbatasan. Sehingga dengan banyaknya penelitianpenelitian baru memberi dampak positif terhadap kemajuan dan kemaslahatan masyarakat petani di pedesaan.

\section{Kepustakaan}

Adiwarman A. Karim. (2008). Bank Islam: Analisis Fiqih dan Keuangan Edisi Ketiga. Jakarta: PT. Raja Grafindo Persada.

Badrudin, Rudy. (2012). Ekonomika Ekonomi Daerah. Edisi Pertama, Yogyakarta : UPP
STIM YKPN. Departemen Ilmu Ekonomi Universitas Padjadjaran.

Badan Pusat Statistik(BPS) diakses dari http://www.bps.go.id/, diakses pada tanggal 2 Februari 2018 pada jam 20.20 WIB.

Badan Pusat Statistik. (2002). Statistik Industri Besar dan Sedang. BPS, Jakarta.

Chapra, M. Umer, (2001), The Future of Economics: An Islamic Perspective. Jakarta, Tim Penerbitan SEBI.

Djaenuddin, dkk. (2003). Petunjuk Teknis Evaluasi Lahan untuk Komoditas Pertanian. Bogor. Balai Penelitian Tanah, Puslitbang Tanah dan Agroklimat.

Ghozali, Imam. (2005). Aplikasi Analisis Multivariate dengan program SPSS, Badan Penerbit Universitas Diponegoro, Semarang.

Gunawan, Asril (2017). Peran Dinas Pertanian Tanaman Pangan dan Hortikultura Kab. Aceh Besar dalam Meningkatkan Ekonomi Masyarakat Kec. Indrapuri. Skripsi. Mahasiswa Fakultas Dakwah dan Komunikasi. Program Studi Manajemen Dakwah.

Hernanto. F. (1996). Ilmu Usahatani. Penebar Swadaya. Jakarta.

Jhingan, M.L. (2010). Ekonomi Pembangunan dan Perencanaan, Terjemahan. Penerbit Rajawali. Jakarta.

Mubyarto, (1989), Pengantar Ekonomi Pertanian, Jakarta : Edisi Ke-tiga, LP3S.

Nazir, Moh. (2009). Metode Penelitian. Jakarta: Ghalia Indonesia.

Sugiyono. (2014). Metode Penelitian Kuantitatif Kualitatif dan R\&D. Bandung : Alfabeta.

Soekartawi. (2002). Analisis Usahatani. Universitas Indonesia Press. Jakarta. 
Purwowidodo. (1999). Pokok-pokok Bahasan Konservasi Tanah di Kawasan

Hutan. Laboratorium Pengaruh Hutan. Fakultas Kehutanan. IPB. Bogor.

Primada, Beny Septyliyan (2015), Tinjauan Mekanisme Kontrak Pengelolaan Lahan pertanian Berbasis Adat Istiadat Dalam Kajian Fiqh Muamalah (Desa Temu, Kec. Kanor, Kab. Bojonegoro). Mahasiswa Program Studi S1 Ekonomi Islam-Fakultas Ekonomi dan BisnisUniversitas Airlangga. 
